\title{
PERANCANGAN SISTEM INFORMASI BADAN PENJAMINAN MUTU INTERNAL STMIK BALIKPAPAN BERBASIS WEBSITE RESPONSIVE
}

\author{
Muhammad Safi'i ${ }^{1)}$, Vidy $^{2}$ \\ ${ }^{1)}$ Manajemen Informatika, STMIK Balikpapan \\ ${ }^{2)}$ Teknik Informatika, STMIK Balikpapan \\ ${ }^{1,2)}$ J1. AMD Manunggal No 09 , Balikpapan, 75111 \\ E-mail : msafii@stmikbpn.ac.id ${ }^{1)}$, vidy@stmikbpn.ac.id ${ }^{2)}$
}

\begin{abstract}
ABSTRAK
Perguruan tinggi STMIK Balikpapan sebagian besar belum menerapkan proses penjaminan mutu, pada hal saat ini penjaminan mutu merupakan tuntutan masyarakat maupun Pemerintah yang tidak bisa dihindari. Salah satu kendalanya adalah belum tersedianya sistem informasi yang dapat menginformasikan kepada seluruh mahasiswa-i, staff karyawan dan dosen di stmik balikpapan. Oleh karena itu, penelitian ini bertujuan untuk merancang kebutuhan aplikasi sistem informasi penjaminan mutu yang mudah di gunakan oleh semua pengguna.

Tujuan dari penelitian ini yaitu untuk membangun Sistem Informasi Penjaminan Mutu Internal STMIK Balikpapan terhadap layanan unit. Model pengembangan sistem yang digunakan adalah RAD ( Rapid Application Develompment) yang mana model RAD ini merupakan adaptasi dari model waterfall versi kecepatan tinggi dan model perangkat lunak yang bersifat inkremental terutama untuk waktu pekerjaan yang pendek. Pengujian yang di gunakan untuk menguji kehandalan aplikasi yang dibangun melalui blackbox test dan alpha test.
\end{abstract}

Kata Kunci: Sistem Informasi, Penjaminan Mutu, Website, Responsive

\section{PENDAHULUAN}

Kehadiran penjaminan mutu dalam lingkungan Perguruan tinggi STMIK Balikpapan secara ideal untuk menjaga kualitas ideology serta akademik. Namun dalam sisi lain kehadirannya dapat didasari alasan lain dan Ditemukan bahwa penyelenggaraan mutu pendidikan merupakan reaksi atas sejumlah perubahan keadaan yang terkait dengan: (a).perubahan konteks yang terkait dengan sebaran profil mahasiswa, internalisasi pendidikan tinggi maupun pasaran kerja. (b) munculnya angkatan kerja dan mahasiswa (c) ketidakpuasan dari pekerja dan mahasiswa (d) desakan karena terbatasnya dana (e) tuntutan untuk melakukan pertanggung jawaban terhadap kelembagaan.

Dalam lingkungan STMIK Balikpapan, sebagian reaksi tersebut terjadi misalnya reaksi atas ketidakpuasan mahasiswa terhadap kurangnya informasi yang berkaitan dengan manajemen mutu dosen dan staff karyawan, selain itu juga desakan untuk keperluan akreditasi perguruan tinggi.

STMIK Balikpapan merupakan suatu perguruan tinggi bidang ilmu komputer yang telah berdiri sejak tanggal 01 februari 2000 memiliki visi "menyelenggarakan pendididkan dan penelitian yang mendukung pembangunan nasional, pengabdian kepada masyarakat yang selaras dengan falsafah perguruan tinggi, membina kehidupan akademik yang sehat, serta mengembangkan serta melestarikan temuan ilmu pengetahuan, teknologi dan humaniora dengan mengoptimalkan pendayagunaan sumberdaya yang ada."

Untuk mewujudkan visi tersebut kini STMIK Balikpapan mempuyai Lembaga Penjaminan Mutu yang ada sejak tahun 2009. sehubungan dengan konsep sistem penjaminan mutu yang telah dikemukakan di atas maka hal tersebut merupakan modal kepercayaan yang harus dibangun oleh STMIK balikpapan. Untuk mendapatkan kepercayaan akan mutu tersebut perlu adanya sebuah sistem penjaminan mutu yang baik dan didukung oleh teknologi informasi yang baik pula.

Berdasarkan pengamatan yang telah dilakukan, saat ini pelaksanaan sistem penjaminan mutu di STMIK Balikpapan sudah mulai dilaksanakan dengan menetapkan standar dan kebijakan mutu, tahapan berikutnya akan dilanjutkan dengan realisasi dan evaluasi dari sistem penjaminan mutu tersebut. Hanya saja pada saat ini sistem penjaminan mutu tersebut masih dilakukan secara manual seperti prosedur dan kebijakan yang ada di arsipkan secara manual, disosialisasikan hanya melalui rapat sehingga adanya keterbatasan akses bagi pihak-pihak yang membutuhkan. Selain itu monitoring dan evaluasi perkuliahan juga dilakukan secara manual sehingga membutuhkan waktu yang cukup lama untuk mendapatkan hasilnya. Oleh karena itu maka dibutuhkan dukungan sistem informasi yang dapat mengakomodasi semua kebutuhan dari sistem penjaminan mutu.

Berdasarkan masalah di atas maka penelitian ini mengusulkan sebuah perancangan sistem informasi penjaminan mutu pada STMIK Balikpapan yang selaras dengan kebutuhan dari sistem penjaminan mutu tersebut. 


\subsection{RUMUSAN MASALAH}

Sebagai upaya mengatasi permasalahan yang telah diuraikan pada latar belakang permasalahan yang akan diteliti adalah "Bagaimana merancang Sistem Informasi penjaminan mutu yang baik dan sesuai dengan kebutuhan yang ada di STMIK balikpapan”

\subsection{BATASAN MASALAH}

Mengingat luasnya ruang lingkup permasalahan yang ada maka batasan masalah yang akan diteliti adalah sebagai berikut

1. Pembuatan sistem Informasi penjaminan mutu berbasis website

2. Website yang dibangun menggunakan teknologi responsive dengan tujuan mempermudah pengguna dalam mengakses website tersebut baik melalui smartphone maupun komputer.

3. Perancangan sistem informasi penjaminan mutu untuk STMIK Balikpapan hanya sebatas prototipe.

4. Perancangan sistem informasi penjaminan mutu untuk STMIK balikpapan menggunakan metode pengembangan sistem RAD (Rapid Application Develompment )

\subsection{TUJUAN PENELITIAN}

Adapun yang menjadi tujuan penelitian ini untuk menghasilkan sistem informasi penjaminan mutu yang diharapkan dapat memberikan kemudahan informasi kepada mahasiswa, staf karyawan dan dosen dimana saja dan kapan saja secaa online

\subsection{MANFAAT PENELITIAN}

Manfaat dari penelitian ini adalah sebagai berikut:

1. Dengan adanya sistem informasi penjaminan mutu ini diharapkan dapat membantu Badan Penjaminan Mutu Internal (BPMI) dalam mengembangkan budaya mutu di lingkungan STMIK balikpapan sesuai dengan visi dan misinya.

2. Dengan adanya sistem informasi penjaminan mutu ini diharapkan dapat mempermudah pihak-pihak terkait khususnya Ketua Program Studi dalam melaksanakan monitoring dan evaluasi (Monev) proses perkuliahan.

3. Sistem informasi penjaminan mutu ini diharapkan dapat mempermudah lembaga penjaminan mutu dalam melaksanakan tugas penjaminan mutunya dengan menyediakan berbagai informasi yang dibutuhkan.

\section{LANDASAN TEORI}

\subsection{SISTEM INFORMASI}

Menurut Jogiyanto, H.M (2008:1) Sistem adalah suatu jaringan kerja dari prosedur-prosedur yang saling berhubungan, berkumpul bersama-sama untuk melakukan suatu kegiatan atau untuk menyelesaikan suatu sasaran yang tertentu.

Menurut Jogiyanto, H.M (2008:8) lnformasi adalah data yang diolah menjadi suatau bentuk yang lebih bereguna dan lebih berarti bagi yang menerimanya. Sumber dari informasi adalah data. Data adalah kenyataan yang menggambarkan suatu kejadian-kejadian dan kesatuan nyata.
Informasi merupakan hal yang sangat penting di dalam pengambilan keputusan. Informasi dapat diperoleh dari sistem informasi (information sistems). Menurut Robert A. Leitch dan K. Roscoe Davis dalam sumber buku Jogiyanto, H.M (2008:11) Sistem informasi didefisikan sebagai berikut : "Sistem informasi adalah suatu sistem di dalam suatu organisasi yang mempertemukan kebutuhan pengolahan transaksi harian, mendukung operasi, bersifat manajerial dan kegiatan strategi dari suatu organisasi dan menyediakan pihak luar tertentu dengan laporan-laporan yang diperlukan".

\subsection{SISTEM PENJAMINAN MUTU PERGURUAN TINGGI (SPM-PT)}

Berdasarkan Permendiknas nomor 63 tahun 2009 penjaminan mutu pendidikan adalah suatu kegiatan sistematik dan terpadu oleh satuan atau program pendidikan, penyelenggaraan satuan atau program pendidikan, pemerintah daerah pemerintah dan masyarakat untuk menaikkan tingkat kecerdasan kehidupan bangsa melalui pendidikan.

Secara umum dapat dikemukakan bawa penjaminan mutu merupakan perencanaan, penerapan, pengendalian dan pengembangan standar mutu perguruan tinggi secara konsisten dan berkelanjutan, sehingga stakeholders, baik internal maupun eksternal memperoleh kepuasan.

SPM-PT merupakan sistem penjaminan mutu penyelenggaraan pendidikan tinggi melalui 3 sub sitem yang masing-masing merupakan sistem pula, yaitu:

a. Pangkalan Data Perguruan Tinggi (PDPT) Nasional

PDPT Nasional merupakan kegiatan sistematik pengumpulan, pengolahan, dan penyimpanan data serta informasi tentang penyelenggaraan pendidikan tinggi di semua perguruan tinggi oleh Ditjen Dikti, untuk mengawasi penyelenggaraan pendidikan tinggi oleh pemerintah.

b. Sistem Penjaminan Mutu Internal (SPMI)

SPMI merupakan kegiatan sistematik penjaminan mutu pendidikan tinggi di perguruan tinggi oleh perguruan tinggi untuk mengawasi penyelenggaraan pendidikan tinggi oleh perguruan tinggi secara berkelanjutan (continuous improvement)

c. Sistem Penjaminan Mutu Eksternal (SPME)

SPME merupakan kegiatan sistemik penilaian kelayakan program dan/atau perguruan tinggi oleh BAN-PT atau lembaga mandiri di luar perguruan tinggi untuk dan atas nama masyarakat, sebagai bentuk akuntabilitas publik.

\subsection{KONSEP PEMODELAN SISTEM 2.3.1 PETA SITUS (SITE MAP)}

Site Map adalah aliran data berbentuk dokumen atau formulir didalam suatu sistem informasi yang merupakan suatu aktivitas yang saling terkait dalam hubungannya dengan kebutuhan data dan informasi. Diagram aliran dokumen merupakan bagan - bagan alir yang menunjukan arus dari laporan dan formulir termasuk tembusantembusannya. Kegunaan dari Site Map ini adalah :

a. Menggambarkan aktivitas apa saja yang sedang berjalan. b. Menjabarkan aliran dokumen yang terlihat.

c. Menjelaskan hubungan - hubungan data dan informasi dengan bagian-bagian dalam aktivitas tersebut. 


\subsubsection{DIAGRAM KONTEKS}

Secara garis besar diagram kontek adalah suatu diagram alir yang tingkat tinggi yang menggambarkan seluruh jaringan, masukan dan keluaran. sistem yang dimaksud adalah untuk menggambarkan sistem yang sedang berjalan. mengidentifikasikan data awal dan akhir yang masuk dan keluaran sistem. Di sini juga bisa di jelaskan fungsi data flow diagram atau (DFD) terbagi atas 3 bagian DFD yaitu:

1. Data Flow Diagram (DFD) adalah alat pembuatan model yang memungkinkan profesional sistem untuk menggambarkan sistem sebagai suatu jaringan proses fungsional yang dihubungkan satu sama lain dengan alur data, baik secara manual maupun komputerisasi.

2. DFD ini adalah salah satu alat pembuatan model yang sering digunakan, khususnya bila fungsi-fungsi sistem merupakan bagian yang lebih penting dan kompleks dari pada data yang dimanipulasi oleh sistem. Dengan kata lain, DFD adalah alat pembuatan model yang memberikan penekanan hanya pada fungsi sistem.

3. DFD ini merupakan alat perancangan sistem yang berorientasi pada alur data dengan konsep dekomposisi dapat digunakan untuk penggambaran analisa maupun rancangan sistem yang mudah dikomunikasikan oleh profesional sistem kepada pemakai maupun pembuat program.

\subsection{MODEL PENGEMBANGAN PERANGKAT LUNAK}

SDLC ( System Development life Cycle) adalah langkah-langkah dalam pengembangan sistem informasi / tahapan-tahapan dala pekerjaan yang dilakukan oleh analis sistem dan programmer dalam membangun system informasi.

\subsection{WEB RESPONSIVE}

Desain Web Responsif (bahasa Inggris:Responsive Web Design (RWD)) adalah sebuah metode atau pendekatan sistem web desain yang bertujuan memberikan pengalaman berselancar yang optimal dalam berbagai perangkat, baik mobile maupun komputer meja. Dengan metode ini, web akan beradaptasi jika dibuka dari perangkat mobile berukuran kecil maupun perangkat komputer meja dengan ukuran monitor besar. Ukuran huruf, user interface, gambar dan tata letak akan menyesuaikan dengan lebar layar dan resolusi layar monitor yang tersedia. Hasilnya pengguna akan merasakan pengalaman mudah membaca, nyaman dan melihat informasi web tersebut sama dengan jika ia melihat melalui perangkat komputer meja.

\section{METODELOGI PENELITIAN}

Kerangka kerja penelitian menggambarkan tahapan proses yang dilakukan dalam penelitian agar penelitian dapat berjalan dengan baik dan tujuan yang telah ditetapkan dapat tercapai. Pada penelitian ini penulis menggunakan tahapan kerangka kerja penelitian sebagai berikut :

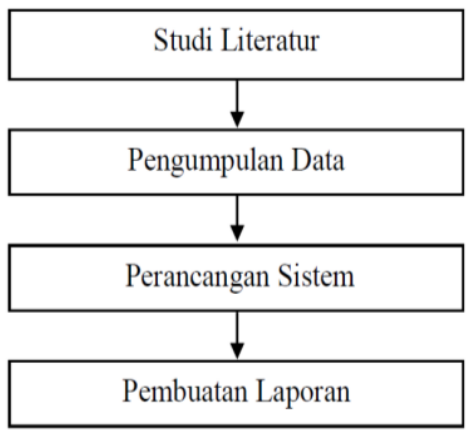

Gambar 1. Kerangka Kerja Penelitian

\section{Studi literatur}

Mempelajari dan memahami teori-teori yang menjadi pedoman dan referensi guna penyelesaian masalah yang dibahas dalam tesis ini dan mempelajari penelitian yang relevan dengan masalah yang diteliti.

2. Pengumpulan data

Mengumpulkan data-data yang berhubungan dengan organisasi yang penulis teliti dengan mengumpulkan dokumen organisasi, melakukan pengamatan dan wawancara dengan pihak-pihak yang terkait.

3. Perancangan Sistem

Membuat rencana prototipe sistem informasi penjaminan mutu dengan menggunakan Diagram flowmap dan diagram konteks :

a. Menentukan perencanaan awal

Pada tahap ini dibuat perencanaan mengenai kegiatan apa saja yang akan dilakukan beserta waktu yang dibutuhkan untuk masing-masing kegiatan.

b. Melakukan analisis proses bisnis

Pada tahap ini dilakukan analisis terhadap proses bisnis yang terjadi pada lembaga penjaminan mutu STMIK Balikpapan.

c. Menganalisis sistem informasi yang digunakan saat ini Pada tahap ini dilakukan analisis terhadapa sistem informasi dan teknologi informasi yang digunakan saat ini dalam mendukung proses bisnis dari lembaga penjaminan mutu di STMIK Balikpapan.

d. Menggambarkan sistem informasi dengan menggunakan Flowmap dan DFD

4. Pembuatan Laporan

Pada tahapan pembuatan laporan dilakukan setelah kegiatan penelitian menghasilkan aplikasi yang sesuai dengan tujuan penelitian.

\section{ANALISIS DAN PERANCANGAN SISTEM \\ 4.1 ANALISIS KEBUTUHAN SISTEM}

Pada tahap analisa kebutuhan sistem merupakan proses untuk menetapkan layanan-layanan (services) yang dibutuhkan user dan admin dari sebuah system serta batasan-batasan dalam pengoperasian system dan pengembangannya. Tahap ini merupakan salah satu tahap yang penting, karena kesalahan dalam mengidentifikasikan permasalahan dalam sistem akan menimbulkan salah persepsi ketika ingin merancang sistem. Hal ini akan berakibat pada kurang efektifnya perancangan yang dibuat. Pada tahapan ini diharapkan dapat membantu pengembang untuk memahami memahami masalah dengan lebih baik dan menghasilkan pemahaman tertulis dari masalaah customer serta untuk mengetahui kebutuhan-kebutuhan 
sistem. Sehingga pada akhirnya nanti akan bisa diusulkan metode-metode perbaikan pada sistem.

\subsection{SITE MAP SISTEM}

Peta situs atau Site Map untuk website Sistem Informasi Badan penjaminan mutu internal STMIK BAlikpapan ini terdiri dari halaman utama (User) dan halaman admin (Administrator) yang dibagi dalam sub menu antara lain

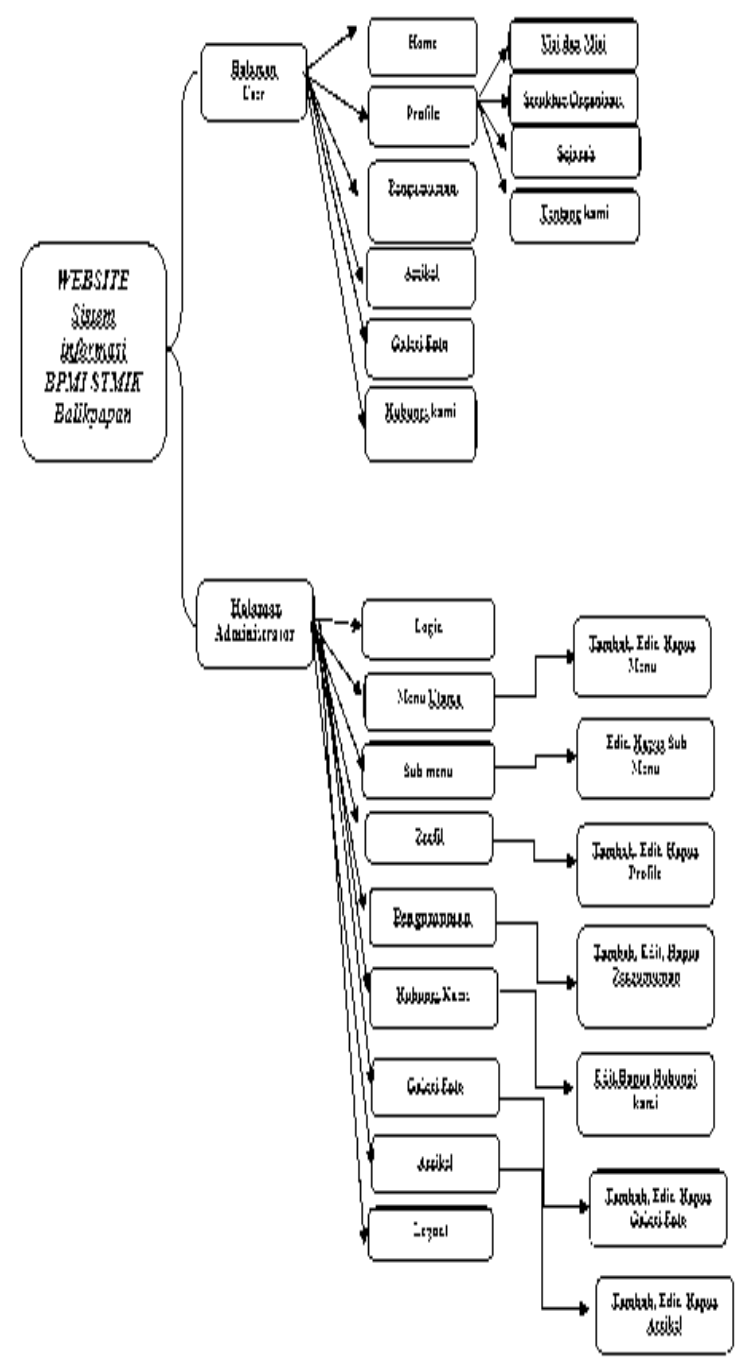

Gambar 2. Site Map sistem

Pada alur site map dapat di ketahui batasan antara user dan admin, untuk user dapat melihat semua isi informasi yang ada didalam website tersebut. Sedangkan untuk admin dapat melakukan proses tambah, edit dan hapus sesuai dengan yang di perlukan.

\subsection{FLOWCHART SISTEM}

Flowchart adalah penggambaran secara grafik dari langkah-langkah dan urut-urutan prosedur dari suatu program. Flowchart menolong analis dan programmer untuk memecahkan masalah kedalam segmen-segmen yang lebih kecil dan menolong dalam menganalisis alternatif-alternatif lain dalam pengoperasian. Berikut adalah flowchart admin yang terdapat pada sistem :

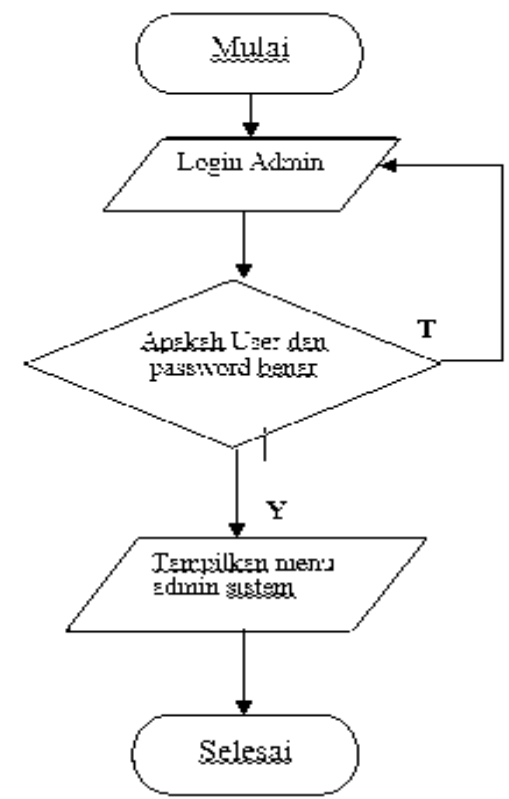

Gambar 3. Flowchart sistem login admin

\subsection{CONTEXT DIAGRAM}

Diagram konteks dari Sistem Informasi BPMI STMIK Balikpapan yang dibuat dapat dilihat pada gambar 4.3 sebagai berikut:

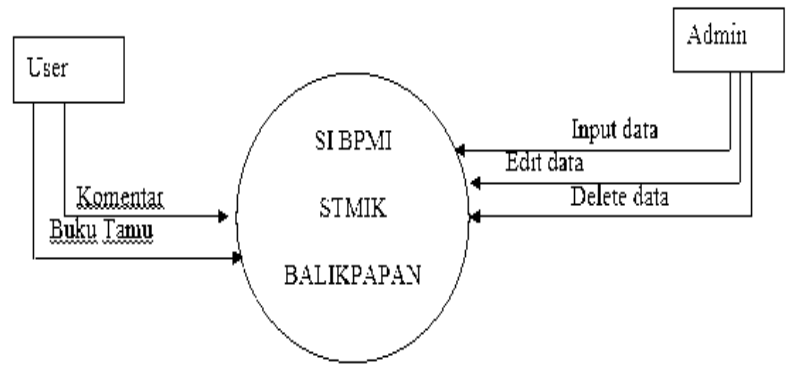

Gambar 4. Conteks Diagram

Pada gambar diatas terdapat 2 pengguna sistemyaitu User dan Admin. Pertama adalah user yang dapat melakukan input komentar terhadap setiap artikel yang di terbitkan oleh admin, kemudian yang kedua dapat mengisi pertanyaan yang ingin di sampaikan berkaitan dengan kegiatan seputar SI BPMI atau kegiatan dalam kampus.

Kedua adalah admin yang mengelola seluruh SI BPMI. Admin dapat melakukan banyak hal mulai dari mengisi artikel, download, pengumuman, galeri foto dan menjawab pertanyaan dari para user. Selain bisa mengisi data admim 
juga dapat melakukan mengedit dan menghapus data bila di perlukan.

\subsection{PERANCANGAN USER INTERFACE}

\subsubsection{Perancangan design user}

Salah satu kriteria penting dari sebuah antarmuka adalah tampilan yang menarik. Seorang pengguna, apalagi pengguna baru, biasanya tertarik untuk mencoba sebuah program aplikasi dengan terlebih dahulu tertarik pada suatu tampilan yang ada di hadapan matanya.

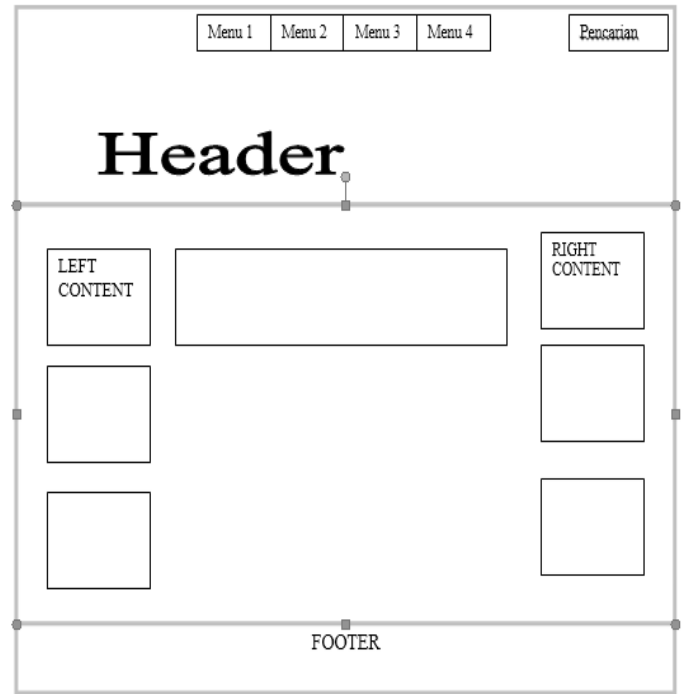

Gambar 5. Perancangan design User Versi Web Komputer

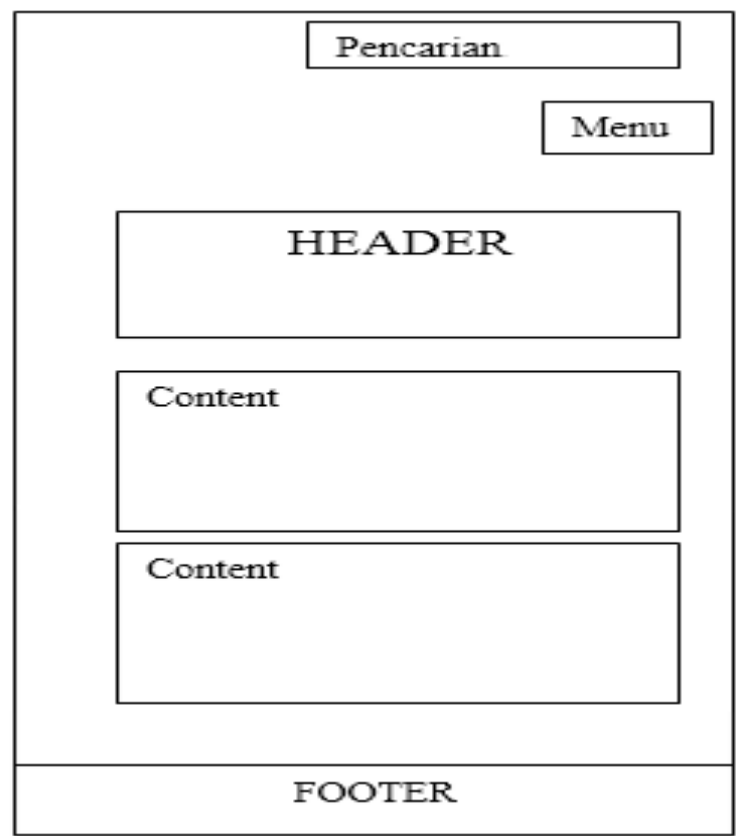

Gambar 6. Perancangan design User Versi Smartphone

\subsubsection{Perancangan design admin}

Pada perancangan design admin akan ditampilkan dalam beberapa menu admin website. Halaman Menu berisi tentang tampilan perubahan yang akan ditampilkan pada halaman menu user dengan cara menambah, mengedit dan menghapus sub menu yang ada di menu user.



Gambar 7. Perancangan design Admin

\section{IMPLEMENTASI ANTAR MUKA}

\subsection{Implementasi User}

Implementasi antarmuka meliputi setiap halaman program yang dibuat beserta pengkodean dalam bentuk file program. Berikut adalah implementasi antarmuka Aplikasi Website SI BPMI STMIK Balikpapan :

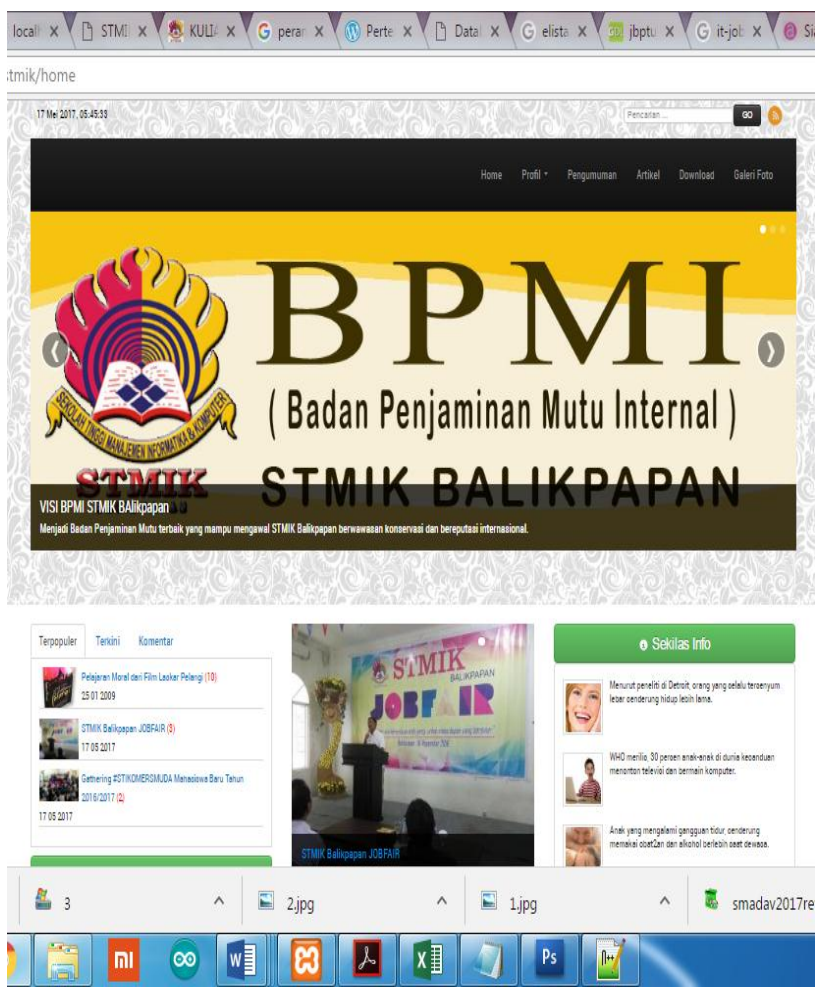

Gambar 8. Implementasi Komputer 


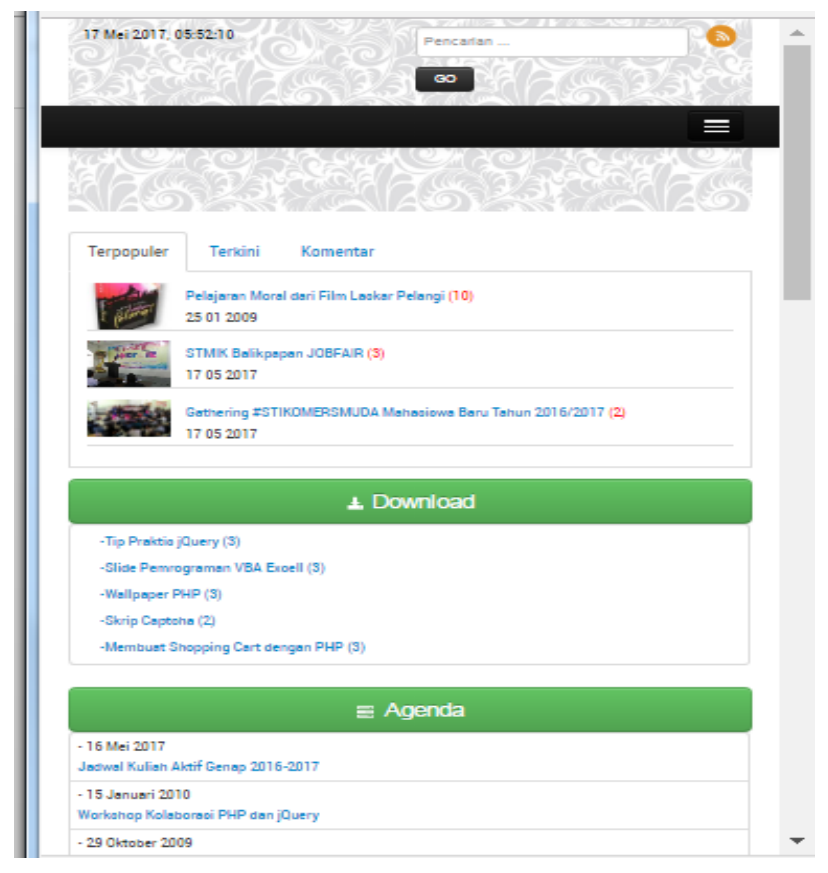

Gambar 9.Implementasi versi Smartphone

\subsection{Implementasi Admin}

administrator adalah orang yang bertugas mengurus hal-hal yang bersifat administratif. Istilah administrator digunakan juga dalam jaringan komputer dan internet dimana administrator atau sering disebut dengan istilah admin memiliki wewenang dan peranan yang besar dalam mengendalikan suatu jaringan komputer, baik lokal maupun internet. Admin yang dimaksud dalam dunia jaringan komputer adalah seseorang atau sebuah tim yang bertindak sebagai pengatur dalam suatu jaringan.



Gambar 10. Implementasi versi Komputer

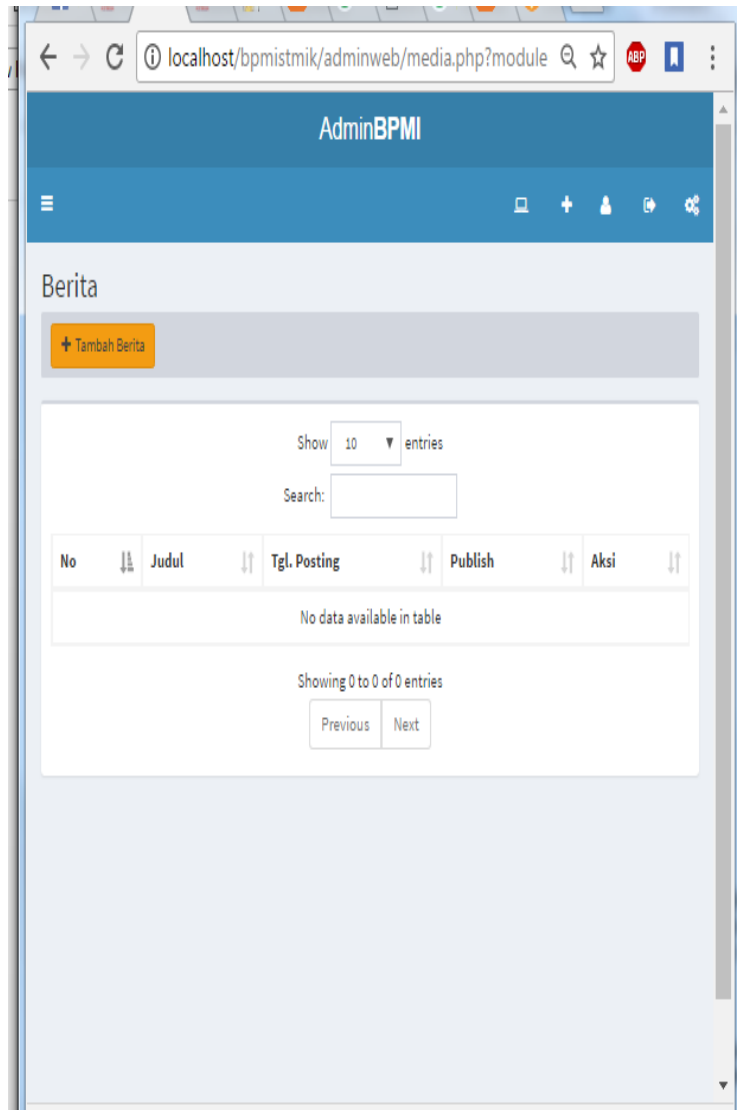

Gambar 11. Implementasi versi Smartphone

\section{KESIMPULAN}

Berdasarkan analisis dan perancangan sistem informasi pada BPMI STMIK Balikpapan maka dapat ditarik kesimpulan sebagai berikut:

1. Sistem penjaminan mutu di STMIK Balikpapan Jambi saat ini baru sebatas pada penetapan kebijakan akademik, standar akademik dan manual prosedur saja. Proses sosialisasi semua manual prosedur, standar akademik dan kebijakan akademik hanya melalui rapat saja sehingga adanya keterbatasan akses bagi pihakpihak yang membutuhkan, karena itu dibutuhkan sebuah rancangan sistem informasi berbasis web yang dapat membantu STMIK BAlikpapan dalam menjalankan sistem penjaminan mutu tersebut.

2. Penelitian ini menghasilkan sebuah prototipe sistem informasi penjaminan mutu STMIK Balikpapan berbasis web responsive yang dapat diimplementasikan lebih lanjut sehingga dapat membantu pelaksanaan sistem penjaminan mutu di STMIK Balikpapan.

3. Prototipe sistem informasi penjaminan mutu ini menyediakan layanan-layanan yang berupa pengelolaan dokumen penunjang monitoring dan evaluasi (Monev) seperti silabus dan SAP, soal dan nilai. Selain itu juga di lengkapai dengan penunjang informasi tentang kegiatan yang ada di PT STMIK Balikpapan melalui menu artikel dan galeri foto. 


\section{SARAN}

Berdasarkan penelitian yang telah dilakukan maka dapat ditambahkan saran-saran sebagai berikut :

1. Prototipe ini belum memperhatikan masalah keamanan data (security), maka untuk penelitian lebih lanjut dapat dilengkapi dengan sistem keamanan data.

2. Penelitian ini dapat dijadikan referensi untuk penelitian selanjutnya yang merupakan implementasi dari penelitian ini sehingga dapat membantu pihak STMIK Balikpapan dalam menjalankan sistem penjaminan mutu yang berkelanjutan guna peningkatan kualitas institusi.

3. Sistem informasi penjaminan mutu ini akan lebih maksimal apabila dalam penerapannya nanti terintegrasi pada sistem informasi yang lain baik akademik maupun non akademik terutama sistem informasi akademik STMIK Balikpapan

\section{DAFTAR PUSTAKA}

Buku Panduan Sistem Penjaminan Mutu Perguruan Tinggi (SPM-PT). Dirjen Dikti. 2010

Buku Panduan Pelaksanaan Sistem Penjaminan Mutu Perguruan Tinggi (SPM-PT) Bidang Akademik. Dirjen Dikti. 2006

Desain website responsive , 2017 https://id.wikipedia.org/wiki/Desain_web_responsif (diakses tanggal 15 mei 2017)

Kisbianty Desi Analisis dan Perancangan Sistem informasi penjaminan mutu pada stikom dinamika bangsa jambi, JURNAL MEDIA SISTEM INFORMASI Vol. 7, No.3, September 2013 hal 42-63

Jogiyanto. 2008. Metodologi Penelitian Sistem Informasi. CV Andi Offset. Yogyakarta 